\begin{tabular}{|l|l|l|}
\hline \multicolumn{2}{|c|}{ PublisherInfo } \\
\hline \hline PublisherName & $:$ & BioMed Central \\
\hline \hline PublisherLocation & $:$ & London \\
\hline \hline PublisherImprintName & $:$ & BioMed Central \\
\hline \hline
\end{tabular}

\title{
ADA deficient mice as a model of eosinophilic pulmonary inflammation
}

\begin{tabular}{||l|l|l||}
\hline \multicolumn{2}{|c||}{ ArticleInfo } \\
\hline \hline ArticleID & $:$ & 1634 \\
\hline \hline ArticleDOI & $:$ & $10.1186 /$ rr-2001-68566 \\
\hline \hline ArticleCitationID & $:$ & 68566 \\
\hline \hline ArticleSequenceNumber & $:$ & 45 \\
\hline \hline ArticleCategory & $:$ & Paper Report \\
\hline \hline ArticleFirstPage & $:$ & 1 \\
\hline \hline ArticleLastPage & $:$ & 4 \\
\hline \hline & & RegistrationDate $: ~ 2001-9-19$ \\
& $:$ & Received $\quad: 2000-11-13$ \\
ArticleHistory & Accepted $\quad: 2001-9-19$ \\
& $:$ & OnlineDate $\quad: 2001-9-19$ \\
\hline \hline ArticleCopyright & $:$ & Biomed Central Ltd2001 \\
\hline \hline ArticleGrants & $:$ & \\
\hline \hline ArticleContext & $:$ & 129312211 \\
\hline \hline
\end{tabular}


Mirco Lusuardi, ${ }^{\text {Aff1 }}$

Corresponding Affiliation: Aff1

Aff1 S Maugeri Foundation, Veruno, (NO), Italy

\section{Keywords}

Adenosine deaminase, alveolar macrophage, asthma, chronic obstructive pulmonary disease, enzyme therapy, eosinophil, transgenic mice

\section{Context}

Adenosine deaminase (ADA) deficiency in humans causes a marked accumulation of adenosine and 2'-deoxyadenosine, which are associated with a variety of phenotypes including combined immunodeficiency, bony and renal abnormalities, hepatocellular damage, neurological disorders and pulmonary insufficiency. The mechanisms involved in these different phenotypes are largely unknown due to the lack of specific models.

Adenosine has a well known role in asthma: elevated levels are found in the bronchoalveolar lavage fluids (BALF) from asthmatics; inhaled adenosine causes bronchoconstriction in asthmatics; airway inflammation is associated with altered expression of adenosine receptors; theophylline has a therapeutic role in asthma as an adenosine receptor antagonist. In vitrostudies indicate a role for adenosine in the inflammatory processes relevant to asthma, such as stimulation of mediator release from mast cells and alteration of eosinophil functions. Adenosine can also influence macrophage and neutrophil functions. Notwithstanding, the exact link between adenosine signalling and lung inflammation is still unclear.

The authors used a genetic engineering strategy to generate ADA-deficient mice and produced a new animal model with severe lung inflammation that develops respiratory insufficiency.

\section{Significant findings}


ADA-deficient mice showed abnormal alveogenesis and severe lung inflammation, characterized by the diffuse accumulation of activated alveolar macrophages and eosinophils in the lungs but not in other tissues. In bronchial airways, hypertrophy of the epithelium, mucus hypersecretion and lumen plugging by mucus and cellular debris were found. Serum IgE and interleukin-5 levels in BALF were elevated. ADA replacement therapy normalized lung adenine nucleoside levels and produced both a reduction of BALF and circulating eosinophils, and a decrease in mucus production in the airways. No effect was noted on lymphopenia. According to the time of administration, enzyme replacement was able either to prevent or reverse pulmonary manifestations, the only exception being the repair of alveogenesis defects. Genetic replacement of ADA prevented the accumulation of adenosine and 2'-deoxyadenosine in the lung and pulmonary alterations.

The authors conclude that this new animal model may help in better understanding human lung conditions in which eosinophils and macrophages are thought to play a pathogenic role, such as asthma, eosinophilic pneumonias, chronic obstructive pulmonary disease and emphysema. New therapies for these conditions can be tested in ADA deficient mice, such as ADA enzyme therapy.

\section{Comments}

This paper reports on the development of a new animal model of potential interest in the study of pulmonary diseases characterized by eosinophil and macrophage infiltration, in particular asthma, chronic obstructive pulmonary disease and eosinophilic pneumonias. ADA deficiency in humans is rare and is mainly associated with a combined immunodeficiency, with only very few patients exhibiting elevated IgE levels, eosinophilia and increased incidence of asthma. Therefore, although the ADA deficient mice model may not be of great relevance to human ADA deficiency, it helps us to understand in more depth the role of purinergic signalling in lung inflammation, especially in relation to the treatment of eosinophil-associated lung disorders and bronchial asthma, in which adenosine has an established role.

\section{Methods}

Generation and genotyping of transgenic mice, quantitative histopathological analysis, immunofluorescence, bronchoalveolar lavage, ELISA assays, ADA enzyme therapy, analysis of ADA enzyme activity, reversed phase HPLC for adenine nucleoside quantitation

\section{Additional information}




\section{References}

1. Blackburn MR, Volmer JB, Thrasher JL, Zhong H, Crosby JR, Lee JJ, Kellerns RE: Metabolic consequences of adenosine deaminase deficiency in mice are associated with defects in alveogenesis, pulmonary inflammation, and airway obstruction. J Exp Med. 2000, 192: 159-170.

This PDF file was created after publication. 